\title{
ATP can be dispensable for prespliceosome formation in yeast
}

\author{
Rhonda Perriman and Manuel Ares, Jr. ${ }^{1}$ \\ Center for Molecular Biology of RNA, Sinsheimer Laboratories, University of California, Santa Cruz, \\ Santa Cruz, California 95064 USA
}

The first ATP-dependent step in pre-mRNA splicing involves the stable binding of U2 snRNP to form the prespliceosome. We show that a prespliceosome-like complex forms in the absence of ATP in yeast extracts lacking the U2 suppressor protein CUS2. These complexes display the same pre-mRNA and U snRNA requirements as authentic prespliceosomes and can be chased through the splicing pathway, indicating that they are a functional intermediate in the spliceosome assembly pathway. ATP-independent prespliceosome-like complexes are also observed in extracts containing a mutant U2 snRNA. Loss of CUS2 does not bypass the role of PRP5, an RNA helicase family member required for ATP-dependent prespliceosome formation. Genetic interactions between CUS2 and a heat-sensitive prp5 allele parallel those observed between CUS2 and U2, and suggest that CUS2 mediates functional interactions between U2 RNA and PRP5. We propose that CUS2 enforces ATP dependence during formation of the prespliceosome by brokering an interaction between PRP5 and the U2 snRNP that depends on correct U2 RNA structure.

[Key Words: Pre-mRNA splicing; spliceosome assembly; prespliceosome; U2 snRNA; CUS2; PRP5]

Received September 15, 1999; revised version accepted November 17, 1999.

The spliceosome is an elaborate ribonucleoprotein machine that recognizes and removes introns from premessenger RNA in the nucleus of eukaryotes. The subunits of the spliceosome are the snRNA-containing U1, U2, U4, U5, and U6 ribonucleoprotein particles (snRNPs). Assembly of the spliceosome on pre-mRNA and progress of the complex through the splicing pathway is a highly ordered process requiring multiple ATP-dependent RNA-RNA or RNA-protein rearrangements and two transesterifications to produce mature mRNAs (for review, see Moore et al. 1993; Ares and Weiser 1995; Kraemer 1996; Staley and Guthrie 1998). Numerous DEXD/ H-box RNA helicase family proteins required at the time of these events have been identified, but exactly what these proteins do and how their activities are regulated is not known (Staley and Guthrie 1998).

In yeast extracts, the first step of spliceosome assembly occurs when the U1 snRNP binds the $5^{\prime}$ splice site of pre-mRNA to form the commitment complex, within which the pre-mRNA branchpoint is also recognized (Ruby and Abelson 1988; Seraphin and Rosbash 1989, 1991; Ruby 1997). Commitment complex formation can proceed in vitro without exogenous ATP (Legrain et al. 1988; Ruby 1997). Stable U2 snRNP binding to the commitment complex forms the prespliceosome and represents the first of several ATP-dependent steps in spliceosome assembly (for review, see Kraemer 1996; Staley and

${ }^{1}$ Corresponding author.

E-MAIL ares@darwin.ucsc.edu; FAX (831) 459-3737.
Guthrie 1998). As the first ATP-dependent step in splicing, prespliceosome formation could provide a key point of regulation for the splicing pathway. Two distinct DEXD/H family members, PRP5 and UAP56, have been implicated in prespliceosome formation (Staley and Guthrie 1998).

Several events are required to make the U2 snRNP competent to enter the splicing pathway prior to prespliceosome formation. In mammalian extracts, three forms of U2 snRNP, the 12S, 15S, and $17 \mathrm{~S}$ forms, have been identified (Behrens et al. 1993; Brosi et al. 1993; Kramer et al. 1999), and only the $17 \mathrm{~S}$ form can be recruited to the assembling spliceosome (Behrens et al. 1993; Brosi et al. 1993). The 17S U2 snRNP contains two multiprotein complexes, SF3a and SF3b, originally identified as factors required for prespliceosome formation (for review, see Kramer 1996). In yeast, homologs of the mammalian SF3a and SF3b protein components have been identified and many have been shown to be required for prespliceosome assembly (Kraemer 1996; Gozani et al. 1996; Wells et al. 1996; Igel et al. 1998; Schmidt-Zachmann et al. 1998; Wang et al. 1998; Caspary et al. 1999; Will et al. 1999; Pauling et al. 2000), suggesting that the roles of these components in prespliceosome formation are conserved. A highly conserved stem-loop of U2 snRNA (stem-loop IIa) positioned just 3' of the branchpoint interaction region in an area of dynamic RNA structure is also required for prespliceosome assembly (Zavanelli and Ares 1991; Zavanelli et al. 1994). Thus, the U2 snRNP must contain appropriate protein and U2 RNA structures to be competent for prespliceosome assembly. How 
these components contribute to correct spliceosome assembly is not known.

During or soon after the SF3-containing U2 snRNP associates with the commitment complex, ATP hydrolysis is required to stabilize prespliceosome formation (for review, see Kramer 1996; Staley and Guthrie 1998). Consistent with this hypothesis, PRP5, a member of the ATP-dependent RNA helicase family, is required for prespliceosome assembly in yeast (Dalbadie-McFarland and Abelson 1990; O'Day et al. 1996). PRP5 shows genetic interactions with stem-loop IIa of U2 snRNA, as well as with SF3a and SF3b proteins (Ruby et al. 1993; Wells and Ares 1994, 1996), suggesting that it functions with the SF3-containing U2 snRNP. Although no physical interaction between PRP5 and any SF3 protein has been observed, the ATPase activity of PRP5 is modestly but specifically increased by U2 snRNA, suggesting that U2 RNA is either a substrate or an activator of PRP5 (O'Day et al. 1996). An oligonucleotide-RNaseH probing experiment suggests that PRP5 modulates the accessibility of the branchpoint interaction region of U2 snRNA within the U2 snRNP (O'Day et al. 1996), yet the relationships between the activity of PRP5, the stem-loop IIa of U2 snRNA, and the role of ATP hydrolysis in prespliceosome formation have not been resolved.

Using genetic suppression of a cold-sensitive U2 stemloop IIa mutant, we identified a novel U2-associated protein, CUS2 (Yan et al. 1998). Although CUS2 protein is not essential, its absence renders lethal certain U2 RNA mutants altered in the region of U2 encompassing stemloop IIa, suggesting a role for CUS2 in aiding formation of stem-loop IIa. Mutation of a CUS2 RNA recognition motif (RRM; Kenan et al. 1991; Birney et al. 1993; Nagai et al. 1995) destroys in vitro RNA-binding activity and abrogates CUS2 activity (Yan et al. 1998), suggesting that CUS2 assists U2 function by binding U2 snRNA. The U2 snRNA mutations rescued by the CUS2 suppressor proteins inhibit formation of stem-loop IIa and U2 snRNP recruitment in vitro (Zavanelli and Ares 1991; Yan et al. 1998), suggesting that CUS2 may help overcome a ratelimiting step in spliceosome assembly that is sensitive to U2 RNA structure.

Here, we provide evidence for a regulatory role of CUS2 and a U2 snRNA structure during prespliceosome assembly. We find that extracts from yeast strains lacking CUS2 protein, or containing a specific mutant U2 snRNA, assemble functional prespliceosome-like complexes in the absence of ATP. The loss of CUS2 does not relieve the requirement for PRP5, and genetic experiments show that overexpression of CUS2 or the coldsensitive U2 suppressors CUS2-9 and CUS2-25 also suppress the heat-sensitive prp5-1 allele. Taken together, our results show that CUS2 helps enforce the ATP dependence of U2 snRNP recruitment and prespliceosome assembly and imply that CUS2 helps couple PRP5 function to ATP-dependent steps in prespliceosome formation. These observations lead to a model in which ATP is not strictly essential for U2 snRNP recruitment but, rather, stimulates the rate of prespliceosome formation under control of CUS2 protein and U2 snRNA.

\section{Results \\ A slow-migrating ATP-independent pre-mRNA complex in CUS2d splicing extracts}

To understand the role of CUS2 in prespliceosome formation, we prepared splicing extracts from yeast strains containing (wild-type) or lacking (CUS2 $\Delta$ ) CUS2. Native gel analysis of spliceosome assembly in these extracts on radiolabeled pre-mRNA shows a fundamental difference in splicing complexes (Fig. 1A). When ATP is present, both extracts produce slower migrating complexes on preactin mRNA, consistent with formation of prespliceosome and spliceosomes $(\mathrm{P} / \mathrm{SP}$, these complexes comigrate in this gel system; Seraphin and Rosbash 1989; Fig. 1A, lanes 1,4). When ATP is depleted from wild-type extracts, only commitment complexes, and no prespliceosomes are observed (CC; Fig. 1A, lane 2), consistent with previous studies in yeast and mammalian splicing extracts (for review, see Kramer 1996). Similarly, only commitment complexes appear upon addition of a nonhydrolyzable ATP analog AMP-PCP to the ATP-depleted wild-type extracts (Fig. 1A, lane 3). In contrast, ATP-depleted or AMP-PCP-containing CUS2 $\Delta$ extracts yield a complex that comigrates with prespliceosomes (Fig. 1A, lanes 5,6). To ensure that ATP depletion of the CUS2 $\Delta$ extract is complete, we tested increasing glucose concentration to $20 \mathrm{~mm}(100 \times$ standard $)$ and observed the same slow migrating complex (data not shown). Three independent ATP-depleted, CUS2 $\Delta$-splicing extracts gave the same slow migrating complex. The ATP-independent complex forms after incubation at temperatures ranging from $15^{\circ} \mathrm{C}$ to $37^{\circ} \mathrm{C}$ (data not shown).

The ATP-independent complex has pre-mRNA and $\operatorname{sn} R A$ requirements identical to authentic prespliceosomes

If the ATP-independent complex in CUS2 2 extracts is functionally equivalent to prespliceosomes, it should display characteristics identical to true prespliceosomes. Previous work shows that prespliceosome formation in yeast and mammalian splicing extracts require an intact $5^{\prime}$ splice site and branchpoint-interacting region on premRNA (for review, see Kramer 1996; Staley and Guthrie 1998). To investigate whether these requirements are also important for the ATP-independent complex, we tested pre-RP51A mRNA lacking a $5^{\prime}$ splice site $\left(5^{\prime}\right)$ or branchpoint interacting region $(\mathrm{BP})$ in ATP-depleted wild-type or CUS2 $\Delta$-splicing extracts (Fig. 1B). No prespliceosomes form on either wild-type or mutant premRNA in the absence of ATP in wild-type extracts (Fig. 1B, lanes 2-4). In contrast, and as for preactin (Fig. 1A), ATP-depleted CUS2 $\Delta$ extracts support formation of slower migrating complexes on wild-type pre-RP51A (Fig. 1B, lane 5), but not on either of the mutant premRNAs (Fig. 1B, lanes 6,7). Like true prespliceosomes, the ATP-independent complex requires a 5 ' splice site and branchpoint region on pre-mRNA. In addition, the ATP-independent prespliceosome-like complex forms on both preactin and pre-RP51A mRNA. 

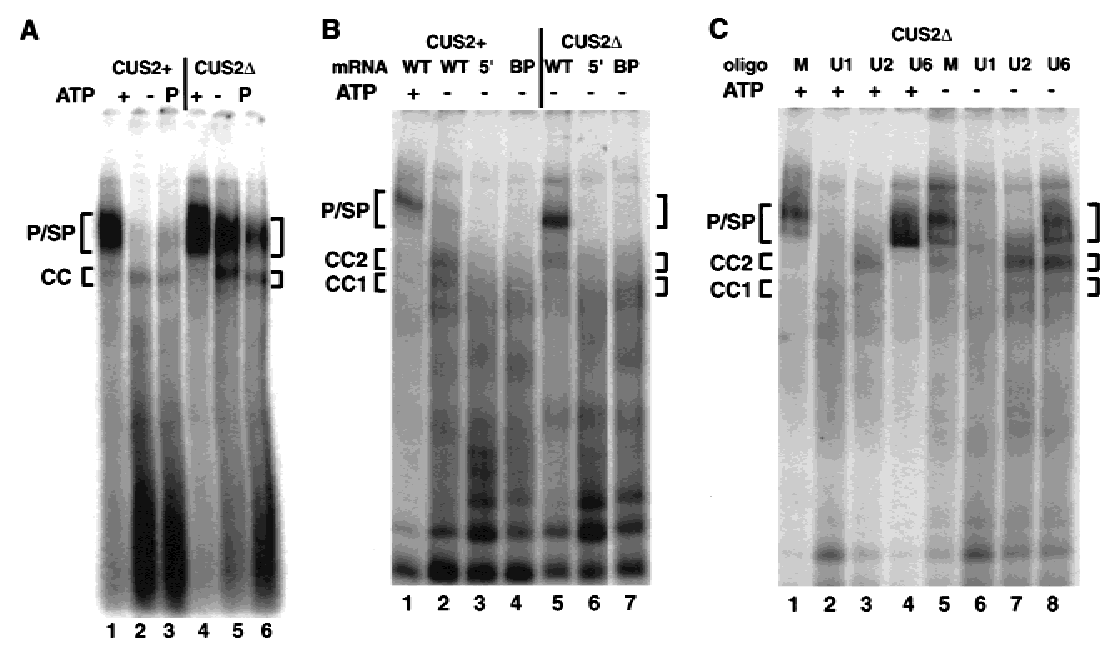

ATP-independent prespliceosome assembly in yeast

(CC1 and CC2) $(C)$ CUS2 $\Delta$ extracts treated with oligonucleotides (10) to U1 (lanes 2,6), Lanes 1-4 have 2 mM ATP added with pre-RP51A substrates after oligonucleotide-ablation; lanes 5-8 have no ATP. Brackets are as for $B$.

Prespliceosome formation requires U1 and U2 snRNAs, but not U6 snRNAs. To test the U snRNA dependence of the ATP-independent complex, we used oligonucleotidedirected RNase $\mathrm{H}$ digestion of $\mathrm{U} 1, \mathrm{U} 2$, or U6 snRNAs (Fig. 1C). Whether ATP is present or not, depletion of U1 snRNA (Fig. 1C, lanes 2,6) results in the loss of both CC1 and CC2 (Legrain et al. 1988; Seraphin and Rosbash 1989), consistent with the U1 snRNA requirement in commitment complex formation (Seraphin and Rosbash 1989). Depletion of U2 snRNAs, with or without ATP (Fig. 1C, lanes 3,7), allows accumulation of CC2 only, consistent with the U2 snRNA requirement in prespliceosome assembly (see Kramer 1996). Depletion of U6 snRNA does not prevent the accumulation of prespliceosomes in the presence of ATP (Fig. 1C, lane 4), nor in ATP-depleted CUS2 $\Delta$ extracts (Fig. 1C, lane 8). Identical U6 snRNA oligo ablation in ATP-depleted wild-type extract results in accumulation of only CC2, demonstrating the ATP requirement for U2 snRNA addition and prespliceosome formation in this extract (data not shown). Thus, like authentic prespliceosomes, the ATPindependent prespliceosome-like complex in CUS2 $\Delta$ extracts requires U1 and U2 snRNA, but not U6 snRNA, for its formation.

\section{The ATP-independent prespliceosome-like complex is splicing competent}

If the ATP-independent complex is functional, it should be competent to splice in a chase experiment (Fig. 2). Traditional chase experiments involving simple ATP addition (Legrain et al. 1988; Seraphin and Rosbash 1989) will be equivocal, due to the presence of commitment complexes in the extract that will also chase to spliceosomes. To prevent commitment complexes from progressing to prespliceosomes and spliceosomes upon ATP addition, we tested the possibility that, once formed, the complex might be resistant to incubation with the U2 oligonucleotide known to inactivate free U2 snRNP (McPheeters et al. 1989; Fig. 2A). We show above that treatment of the CUS2 $\Delta$ extract with the U2 oligonucleotide before pre-mRNA addition abolishes formation of the complex (Fig. 1C, lane 7; Fig. 2A, lane 3). In contrast, oligonucleotide treatment after complexes are allowed to form in the CUS $2 \Delta$ extract has little effect on the amount of the ATP-independent complexes observed (Fig. 2A, lane 4). To test whether these complexes can be chased to spliceosomes in the absence of additional U2 snRNP, we simply add ATP (see Fig. 2C).

Addition of ATP following U2 oligonucleotide treatment of complexes formed in ATP-depleted CUS2s splicing extracts results in pre-mRNA splicing, as assayed by the appearance of intermediates and spliced products (Fig. 2B, lane 6, and C). No splicing occurs without the addition of ATP (Fig. 2B, lane 4), or when the U2 oligonucleotide is added prior to ATP-independent complex formation (Fig. 2B, lanes 3,5). Identical treatment of a CUS2-containing (wild-type) extract does not result in significant splicing (Fig. 2B, lane 12), because prespliceosome formation normally requires ATP. This control shows that the U2 oligonucleotide treatment effectively prevents any commitment complexes from being chased. We conclude that the complex is a functional prespliceosome that forms in the absence of ATP and CUS2, and suggest that this prespliceosome-like complex is a previously undetected intermediate in the spliceosome assembly pathway.

\section{Addition of recombinant CUS2 restores ATP dependence of prespliceosome formation}

To show that CUS2 protein enforces the ATP dependence of prespliceosome formation, we added bacterially expressed wild-type (rCUS2; Yan et al. 1998), or an RNAbinding defective CUS2 mutant (rY48D; Yan et al. 1998) to CUS2 $\Delta$ splicing reactions (Fig. 3A). Addition of $350 \mathrm{~nm}$ rCUS2, but not rY48D or buffer alone, inhibits formation 
Figure 2. The novel ATP-independent complex can chase to spliceosomes. $(A)$ The complex is resistant to U2 oligonucleotide. Native gel analysis of complexes formed with no U2 oligonucleotide (lanes 1,2), 45 nм U2 oligonucleotide before (lane 3) or after (lane 4) adding preactin. Lane 1 has $2 \mathrm{~mm}$ ATP. Bracketed species as for Fig. 1A. (B) Analysis of preactin RNA-spliced products after treatments 1 or 2. Lanes 2-6 are splicing reactions done in ATP-depleted, CUS $2 \Delta$ extracts. Lanes 7-12 are identical splicing reactions done in CUS2+ extracts. Lanes 1 and $7(\mathrm{C})$ contain $2 \mathrm{~mm}$ ATP and preactin, but no U2 oligonucleotide. Lane $M$ is untreated preactin. Splice products from top to bottom of gel are as follows: lariat-3' exon; excised lariat; precursor preactin; mature actin mRNA; released $5^{\prime}$ exon. $(C)$ Schematic representation of two treatments for chasing the ATP-independent prespliceosome to spliceosomes.

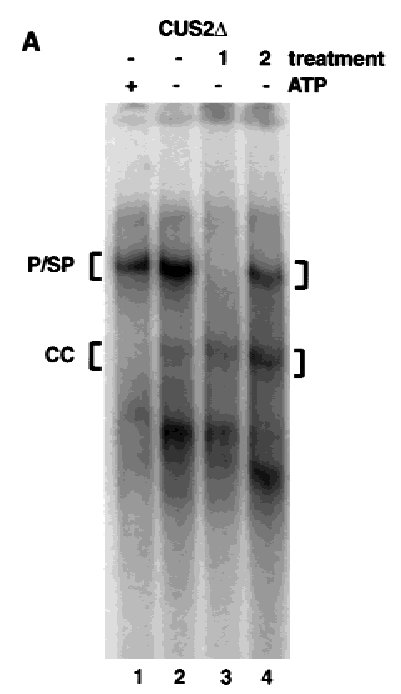

B

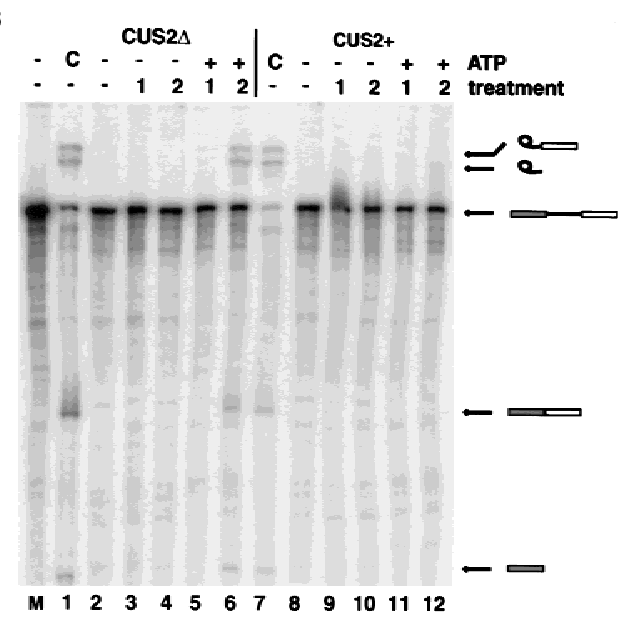

C

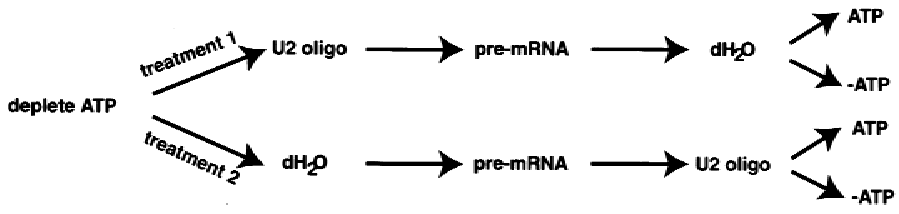

of the ATP-independent prespliceosome-like complex (Fig. 3A, lane 2 vs. lane 5 vs. lane 8). This concentration of rCUS2 does not inhibit splicing because splicing complex formation and splicing proceeds normally in the presence of rCUS2 upon addition of ATP (data not shown). We conclude that rCUS2 protein restores the normal ATP dependence of prespliceosome formation to CUS2 $\Delta$ extracts and that it requires an intact RNA-binding activity to perform this role.

\section{ATP stimulation of prespliceosome formation remains intact in CUS2 2 extracts}

To determine whether CUS2 depletion blocks the ability of ATP to stimulate prespliceosome assembly, we assayed the rate of prespliceosome formation in CUS2+ and CUS $2 \Delta$ extracts with ATP and in CUS $2 \Delta$ extracts without ATP (Fig. 3B). To ensure that spliceosome assembly does not proceed beyond prespliceosomes, we used U6 snRNA-depleted extracts. ATP-dependent prespliceosome formation peaks $\sim 5$ min after pre-mRNA addition in both CUS2+ and CUS2 $\Delta$ splicing extracts and then declines steadily at later timepoints (Fig. 3B, lanes $8-10,13-15)$. In contrast, the rate of ATP-independent prespliceosome-like complex formation in CUS $2 \Delta$ extracts is greatly reduced, with little complex formation observed until $\sim 20 \mathrm{~min}$ after pre-mRNA addition. Furthermore, the ATP-independent prespliceosome-like
Figure 3. (A) rCUS2 addition disrupts formation of the novel ATP-independent complex. Addition of protein dilution buffer (B, lane 2), 50, 100, or $350 \mathrm{nM}$ rCUS2 (lanes 3-5), or rY48D (lanes 6-8). Lane 1 has $2 \mathrm{~mm}$ ATP and protein dilution buffer. Brackets are as for Fig. 2. $(B)$ The rate of formation of ATP-independent prespliceosomes is reduced compared with ATP-dependent prespliceosomes. Analysis of complexes formed on pre-RP51A after addition to U6-depleted CUS2 $\Delta$ (lanes 1-10) or CUS2+ (lanes 11-15) splicing extracts. Lanes 1-5 are ATP depleted, lanes 6-15 contain 2 mM ATP. Samples were taken at 0 (lanes 1,6,11), 1 (lanes 2,7,12), 5 (lanes $3,8,13$ ), 20 (lanes 4,9,14), or 40 (lanes $5,10,15)$ min after addition of preRP51A. Brackets are as for Fig. 2.
A

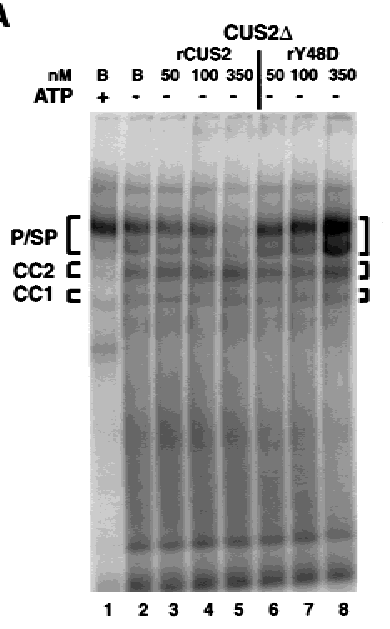

B

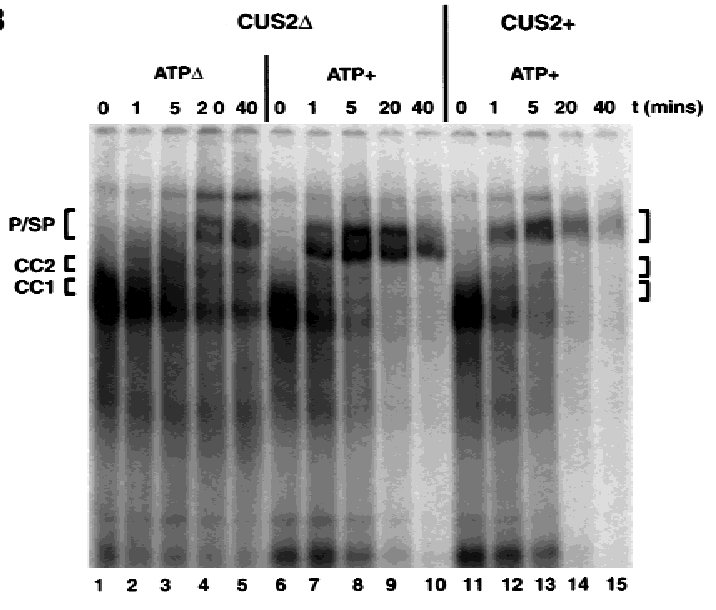


complexes continue to accumulate up to $80 \mathrm{~min}$ after pre-mRNA addition (Fig. 3B, lane 5; data not shown). We conclude that ATP significantly stimulates the rate of prespliceosome formation by a mechanism that does not require CUS2 protein.

\section{PRP5 is required for prespliceosome assembly in CUS2 $\Delta$ splicing extracts}

Our data suggest that ATP is not required to form prespliceosome-like complexes in the absence of CUS2. Because the DEAD-box protein PRP5 is required for ATPdependent prespliceosome formation (Dalbadie-McFarland and Abelson 1990; Ruby et al. 1993; O'Day et al. 1996), we were curious to learn whether this protein is still required in the absence of CUS2. To do this, we crossed the cus2::HIS3 knockout strain with either of two yeast strains carrying the temperature-sensitive PRP5 alleles, prp5-1 and prp5-3, and isolated haploid spores from each cross by tetrad dissection (see below and Fig. 4B). Splicing extracts were isolated from the prp5-1, cus2::HIS3 strain and a sibling prp5-1, CUS2 strain and analyzed for formation of ATP-dependent prespliceosomes at permissive $\left(25^{\circ} \mathrm{C}\right)$ and restrictive $\left(37^{\circ} \mathrm{C}\right)$ temperatures in vitro (Fig. 4A).

Both strains efficiently form prespliceosomes after pretreatment at $25^{\circ} \mathrm{C}$ followed by incubation at $25^{\circ} \mathrm{C}$ in the presence of ATP (Fig. 4A, lanes 1,2). In contrast, neither the prp5-1, cus2::HIS3, nor the prp5-1, CUS2+ splicing extracts form prespliceosomes after pretreatment at $37^{\circ} \mathrm{C}$ followed by incubation at $25^{\circ} \mathrm{C}$ (Fig. 4A, lanes 4,5 ). These results show that removing CUS2 does not bypass the role of PRP5 in presplicesome formation and indicate that a functional PRP5 protein is still required.

\section{Genetic interactions between PRP5 and CUS2}

Crosses between the CUS2 knockout and each of prp5-1 and prp5-3 strains and analysis of the haploid progeny has revealed a synthetic lethal interaction between CUS2 and PRP5. In crosses between cus2::HIS3, PRP5 and CUS2, prp5-1 strains, we find that the double-mutant cus2::HIS3, prp5-1 recombinant progeny are viable but have doubling times $\sim 30 \%$ slower than CUS2, prp5-1 parental or progeny strains at $25^{\circ} \mathrm{C}$ (Fig. 4B). In similar crosses with the prp5-3 allele, double-mutant cus2::HIS3, prp5-3 spores (identified as $\mathrm{His}^{+}$and temperature sensitive) could not be recovered, despite the fact that CUS2 and PRP5 are unlinked. To prove that the cus2::HIS3, prp5-3 combination is lethal, we transformed the diploid strain used in the above cross with a URA3 plasmid bearing the CUS2 gene. After tetrad dissection of this strain, $\mathrm{His}^{+}$, temperature-sensitive spores were readily obtained and invariably were $\mathrm{Ura}^{+}$, indicating that the combination of cus2::HIS3 and prp5-3 is lethal unless covered by a wild-type CUS2 gene. This strain will not grow on 5FOA medium that selects for cells that lose the URA3 plasmid, confirming that the CUS2 knockout allele is synthetic lethal with prp5-3.

CUS2 was originally isolated as a dominant, haplosufficient suppressor of cold-sensitive U2 snRNA mutations (Wells et al. 1996), and it was subsequently shown that the CUS2 knockout is synthetic lethal with a subset of U2 mutations that are misfolded (Yan et al. 1998). Some of the same U2 mutations are synthetic lethal with prp5-1 and prp5-3 (Ruby et al. 1993; Wells and Ares 1994), and U2 RNA can stimulate the ATPase activity of PRP5 (O'Day et al. 1996). This lead us to hypothesize that CUS2 might rescue U2 mutants by activating PRP5 and, therefore, that overexpression of CUS2 or the CUS2 suppressors might rescue the temperature-sensitive phenotype of the prp5 alleles even in combination with wild-type U2. To test this hypothesis, we transformed plasmids carrying CUS2, CUS2-9, or CUS2-25 into the prp5-1 and prp5-3 strains and analyzed growth at $25^{\circ} \mathrm{C}$ and $36^{\circ} \mathrm{C}$ (Fig. $4 \mathrm{C}$; data not shown). Wild-type CUS2 and both the CUS2 suppressors dramatically rescue prp5-1

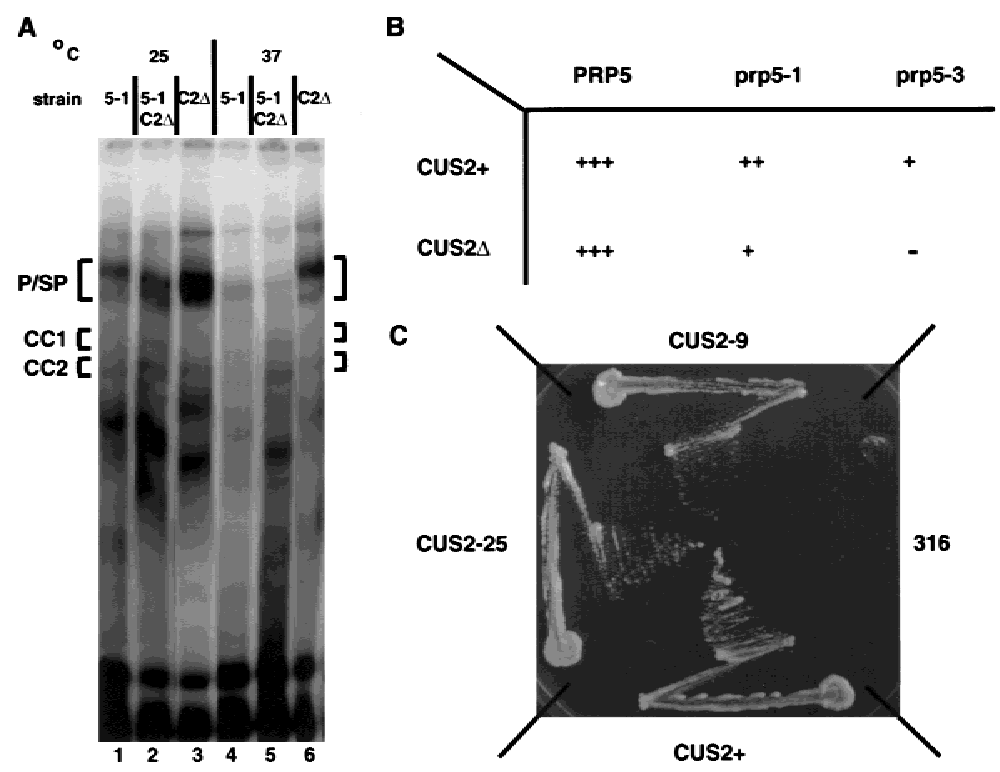

Figure 4. (A) CUS2 2 cannot bypass the requirement for Prp5 in prespliceosome assembly. Splicing extracts isolated from prp5-1 (Ruby et al. 1993) yeast strains containing CUS2 (lanes 1,4) or genetically depleted for CUS2 (lanes 2,5) were incubated at $25^{\circ} \mathrm{C}$ (lanes 1-3) or $37^{\circ} \mathrm{C}$ (lanes 4-6) prior to addition of pre-RP51A. Lanes 3 and 6 contain CUS2 $\Delta$ splicing extracts containing wild-type PRP5 preincubated at $25^{\circ} \mathrm{C}$ (lane 3) or $37^{\circ} \mathrm{C}$ (lanes 6). Brackets are as for Fig. 3. (B) CUS2 and PRP5 show a genetic interaction. Analysis of growth at $25^{\circ} \mathrm{C}$ of strains containing wild-type or one of prp5-1 or prp5-3 temperaturesensitive mutations of PRP5 in combination with wild type or CUS2 $\Delta .(+++)$ Wild-type growth; $(++)$ intermediate growth; $(+)$ slow growth; $(-)$ dead. $(C)$ CUS2-9 and CUS2-25 suppressor proteins can suppress temperature sensitivity of the prp5-1 allele. Growth of SRY5-1 with URA+ plasmids expressing one of wild-type, or CUS2 suppressor proteins as indicated. The plate was incubated at $36^{\circ} \mathrm{C}$ for 4 days. 
temperature sensitivity, but not that of prp5-3. Taken together, the genetic data reveal a complex, allele-specific set of interactions between CUS2 and PRP5, suggesting that they work together during prespliceosome assembly.

\section{A U2 snRNA mutation also relaxes the ATP requirement for prespliceosome formation}

If the absence of CUS2, a protein that modulates the effect of U2 RNA folding mutations (Yan et al. 1998), relaxes ATP dependence of prespliceosome formation (Figs. 1-4), then perhaps U2 RNA is also involved in enforcing ATP dependence. To explore the relationship between U2 snRNA structure and the ATP dependence of prespliceosome assembly when CUS2 protein is present, we analyzed extracts from a yeast strain expressing a mutant U2 snRNA that is altered in a conserved but dispensable sequence able to base pair with loop IIa (Ares and Igel 1990; Zavanelli and Ares 1991; Zavanelli et al. 1994; U2-QMB'; Fig. 5A). This mutant was selected because it disrupts the capacity to form the alternate basepairing conformation, and we hypothesized that the potential to form this base-pairing interaction might also affect the ATP requirement for prespliceosome formation.

Like the CUS2 $\Delta$ extracts, splicing extracts from strains expressing U2-QMB' display ATP-independent prespliceosome-like complexes (Fig. 5B) with identical U snRNA (Fig. 5C) and pre-mRNA (data not shown) requirements to authentic prespliceosomes. Thus, ATPindependent prespliceosomes can form when either CUS2 is absent or the structured region of U2 snRNA just downstream of the branchpoint interaction sequence is perturbed as in the $\mathrm{QMB}^{\prime}$ mutant. A simple interpretation of these results is that both U2 RNA and
CUS2 enforce the ATP dependence of prespliceosome formation and that they do so by working together.

\section{Discussion \\ CUS2 enforces ATP dependence of a prespliceosome assembly step that requires PRP5 in vitro}

Extracts from yeast strains lacking either the U2-associated splicing factor CUS2 or the downstream conserved region of U2 snRNA can form prespliceosome-like complexes under ATP-depleted conditions (Figs. 1-5). By successfully chasing these ATP-independent complexes through the splicing pathway, we provide evidence that they are functionally equivalent to bonafide prespliceosomes (Fig. 2). Addition of recombinant CUS2 protein restores the ATP dependence of prespliceosome formation to CUS $2 \Delta$ extracts, demonstrating that CUS2 is responsible for enforcing ATP dependence (Fig. 3A). The absence of CUS2 does not bypass the function of PRP5 in formation of prespliceosomes in the presence of ATP in vitro (Fig. 4A). These data are consistent with a model whereby U2 snRNP addition to the spliceosome does not strictly require ATP, but is under the negative control of CUS2, which blocks this activity unless ATP is present (Fig. 6). Consistent with genetic interactions between CUS2 and PRP5 (Fig. 4) and the increased rate of prespliceosome formation upon addition of ATP (Fig. 3B), we suggest that CUS2 mediates PRP5 activity. This regulation of PRP5 activity must also involve correct U2 structure, either as a substrate, a product, or an activator, or some combination of all, as a mutation in U2 RNA also results in relaxed ATP dependence of prespliceosome formation (Fig. 5).

The demonstration that U2 snRNP can be stably recruited to a complex functionally equivalent to prespliceosomes in the absence of exogenous ATP is surprising.
Figure 5. Splicing extracts from yeast strains containing CUS2 and mutant U2 allele, U2-QMB' also form prespliceosomes without ATP. (A) Secondary structure fold of a $5^{\prime}$ portion (from nucleotides 48-120) of yeast U2 snRNA showing base substitutions in U2-QMB' ${ }^{\prime}$. The essential stem-loop IIa and conserved structural feature, stem IIb are indicated. The phylogenetically conserved downstream region is in boldface. $(B)$ Native gel analysis of complex formation on pre-RP51A in ATPdepleted splicing extracts from CUS2+, U2-QMB' yeast strains. (Lane 1) $2 \mathrm{~mm}$ ATP; (lane 2) 2 mM AMP-PCP; (lane 3) no additions. Bracketed species are as for Figs. 1 and 2. (C) Native gel analysis of $U$ snRNA requirements for ATP-independent prespliceosomes in splicing extracts from U2-QMB' expressing yeast. Extracts were treated with oligonucleotides designed toanneal to U1 (lanes 2,6), U2 (lanes 3,7), and U6 snRNAs (lanes 4,8). (Lanes 1-4) 2 mM ATP with pre-RP51A substrates after the oligonucleotide-ablation; (lanes 5-8) no ATP. Brackets are as for B.

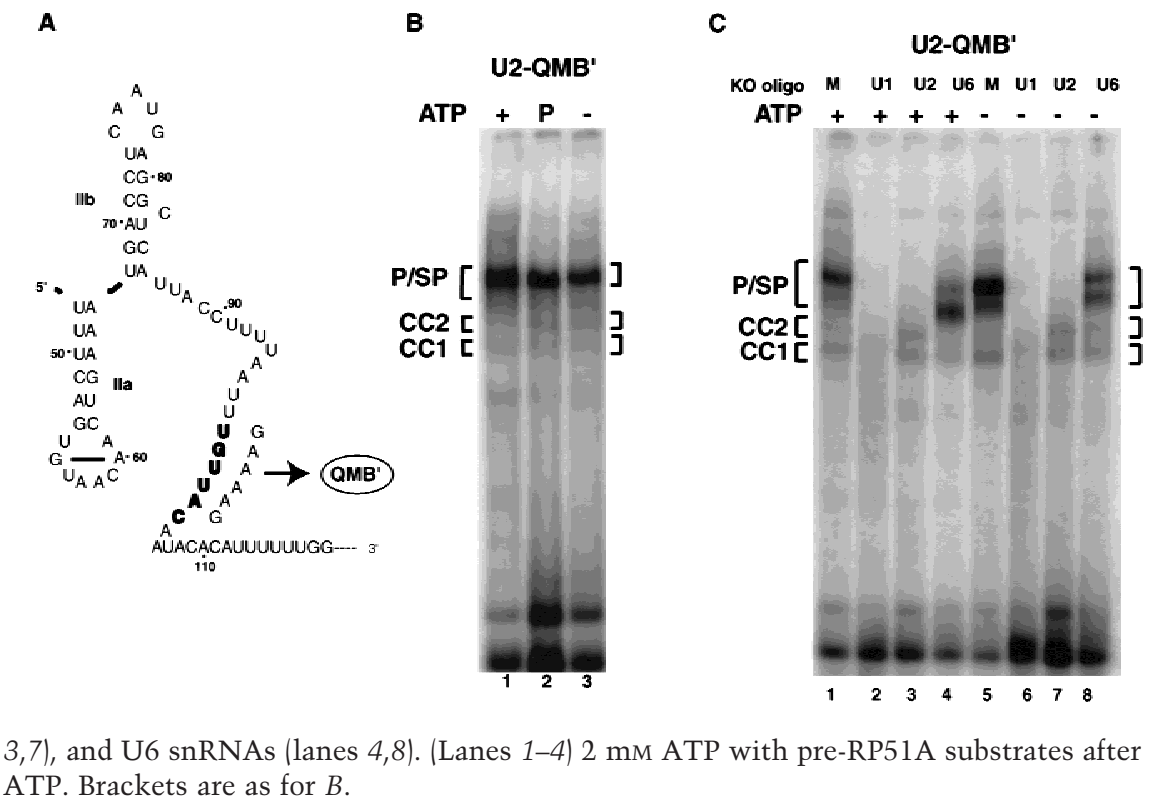

A
C 
A

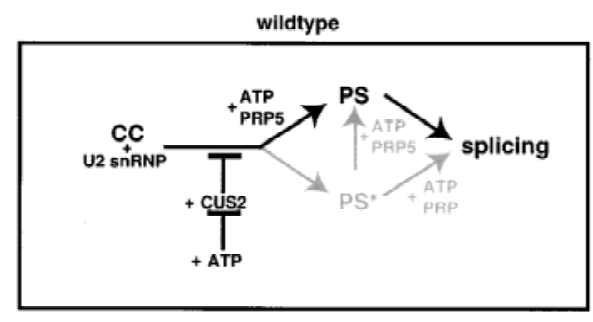

B

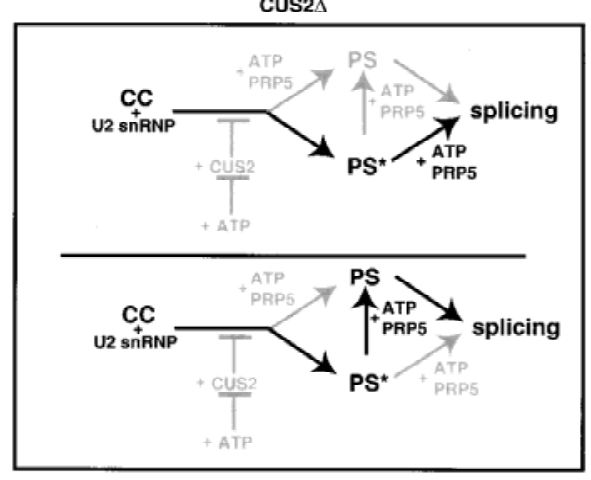

Figure 6. A working model for the role of CUS2 in regulating the ATP dependence of U2 snRNP recruitment and prespliceosome assembly. (A) In the presence of CUS2, U2 snRNP recruitment and prespliceosome formation cannot proceed without the addition of ATP (black pathway). (B) Without CUS2 protein, the U2 snRNP can enter the splicing pathway without ATP to form the functional intermediate prespliceosome-like complex $\left(\mathrm{PS}^{\star}\right)$. Because we cannot distinguish between PS* being on the same or alternate splicing pathways, both possibilities are depicted. As for $A$, the black pathway represents each alternative. Loss of CUS2 does not bypass the requirement for PRP5 and ATP in the formation of ATP-dependent prespliceosomes, hence, both pathways in $B$ show steps beyond PS* requiring both PRP5 and ATP.

Although we do not know whether the ATP-independent prespliceosome-like complex is identical to bonafide prespliceosomes or whether this complex is actually part of the normal splicing pathway (see Fig. 6), our results do indicate that the energy of ATP is not strictly required for U2 recruitment of a functional spliceosome, and implies that ATP hydrolysis has a regulatory or rate stimulatory role in the process. Linking ATP hydrolysis to this critical step in spliceosome assembly might ensure accuracy of timing and fidelity of U2 snRNP addition, as suggested for other nucleotide hydrolysis events in splicing and translation (see Staley and Guthrie 1998; Wilson and Noller 1998). However, the efficiency with which the ATP-independent prespliceosome-like complexes can be chased to functional spliceosomes is high, arguing that most of these complexes are correctly assembled. Inspection of the length of the cleaved exon 1 intermediate and the spliced exon product, as well as the migration of the lariat intermediate and lariat product (Fig. 2B) indicates that branchpoint usage and splice-site cleavage and ligation are accurate, arguing against, but not strictly excluding, a role for ATP in the fidelity of U2 snRNP binding. One role for CUS2 may be to link splicing with the availability of ATP, and hence the other metabolic activities of the cell, providing metabolic regulation at an early point in the splicing process.

The addition of ATP enhances the rate of bonafide prespliceosome formation in CUS2 $\Delta$ extracts (Fig. 3B), indicating that CUS2 protein is not required for this stimulatory effect, rather, it may be acting on factors that are required for the effect. This points to the existence of an ATP-stimulated accessory factor, whose activity is controlled in part by CUS2 and U2 snRNA. Although we favor PRP5 at this point, one other ATP-dependent RNA helicase family member, mammalian UAP56, has been implicated in a step that leads to U2 snRNP recruitment and prespliceosome formation (Fleckner et al. 1997). A predicted yeast ORF (YDL084w) is $>61 \%$ identical to mammalian UAP56, and the role of this protein in splicing in yeast has yet to be determined (Staley and Guthrie 1998). Using prp5 mutant extracts that are also genetically depleted for CUS2, we were able to test whether PRP5 function is bypassed in CUS2A extracts (Fig. 4A). We found that PRP5 is still required for prespliceosome formation in the absence of CUS2. Preliminary data also hints that PRP5 might also play a role in the formation of the ATP-independent prespliceosome-like complex (data not shown). This data in turn suggests that PRP5 may carry out part of its functional cycle without ATP. Two distinct functions, one ATP dependent and the other ATP independent, have been described for another RNA helicase family member, PRP22 (Schwer and Gross 1998).

\section{A second activity of CUS2 enhances PRP5 function in vivo}

Robust genetic interactions between CUS2 and PRP5 indicate that CUS2 activates PRP5 function in vivo (Fig. 4B). For example, when CUS2 is absent, the normally temperature-sensitive prp5-3 allele is lethal, and overexpression of either CUS2 or the CUS2 suppressor alleles allow the normally temperature-sensitive prp5-1 mutants to grow well at $36^{\circ} \mathrm{C}$ (Fig. 4C). Because CUS2 is not essential, and because it seems unlikely that ATP would be absent in vivo, the enforcement of ATP dependence of prespliceosome assembly by CUS2 may be important for the coordination and efficiency of early spliceosome assembly events, and this may be reflected in its apparent contribution to PRP5 activity (Fig. 4). CUS2 is associated with a fraction of U2 snRNPs in vitro and has a strong two-hybrid interaction with PRP11, a yeast SF3a subunit (Yan et al. 1998). Recent results indicate that CUS2 also interacts with HSH155, the homolog of mammalian SF3b subunit SAP155 (H. Igel, R. Perriman, and M. Ares, unpubl.). These putative protein-protein interactions, together with the effect of CUS2 mutations on U2 snRNA function (Yan et al. 1998), suggest that the observed activation of PRP5 function by CUS2 occurs at 
the point where PRP5 acts with the U2 snRNP. Despite many efforts, we have not found evidence for physical interactions between PRP5 and the U2 snRNP or any individual U2 snRNP protein including CUS2. It seems likely that if there is a direct interaction, it is fleeting, and that CUS2 affects the U2 snRNP in terms of U2 RNA structure and interaction with SF3a and SF3b subunits, thereby enhancing PRP5 function. The relationship between the two functions of CUS2, enforcement of ATP dependence of prespliceosome assembly, and activation of PRP5 activity is not yet clear, but if CUS2 is as intimately involved in regulating PRP5 activity as our results indicate, these two functions may be mechanistically related.

\section{U2 RNA and the ATP dependence} of prespliceosome assembly

The effect of CUS2 depletion on splicing complex formation (Figs. 1-4) and genetic interactions between CUS2 and U2 (Yan et al. 1998) prompted us to assess the effect of U2 RNA mutation on the ATP dependence of prespliceosome formation (Fig. 5). The finding that perturbation of U2 RNA structure relieves the requirement for ATP in the presence of CUS2 (Fig. 5B,C) suggests that to enforce the ATP requirement, CUS2 must interact with correctly structured U2 snRNA. Supporting this interpretation are a number of observations. First, a mutant form of CUS2 (rY48D) lacking RNA-binding activity fails to enforce ATP dependence in vitro, whereas the wild-type protein does (Fig. 3A), suggesting that this activity requires RNA binding. Second, the U2 alleles that interact genetically with CUS2 are altered in or near stem-loop IIa, a U2 structure required for prespliceosome assembly in vitro (Zavanelli and Ares 1991), suggesting that the function of this part of U2 is supported by CUS2. Third, CUS2 interacts genetically with PRP5 mutations in a fashion similar to the way it interacts with U2 mutations (Fig. 4; Yan et al. 1998), indicating that CUS2 supports PRP5 function as it supports U2 function. Fourth, the activity of PRP5 is influenced by U2 RNA in vitro (O'Day et al. 1996), and itself influences the structure of the U2 snRNP (Wiest et al. 1996). These findings argue that U2 RNA structure and PRP5 function are intimately related, although it is not possible with the present data to determine whether U2 RNA is an activator or a substrate for either CUS2 or PRP5 activity.

The ability of mutant U2 RNA to participate in ATPindependent prespliceosome-like complex formation in the presence of CUS2 suggests that CUS2 function can be bypassed by appropriately structured U2 RNA. We have tested a variety of U2 mutations in an attempt to discern the particular U2 RNA conformation of CUS2 function (R. Perriman and M. Ares, Jr., unpubl.), but the simple idea that interconversion between the stem-loop IIa-containing form and the alternative conformation of U2 RNA (perhaps by PRP5, Zavanelli and Ares 1991; Zavanelli et al. 1994; O’Day et al. 1996; Wiest et al. 1996) might explain these effects is not yet supported. Additional experiments will be necessary to determine the relationship between U2 structure, CUS2 and PRP5 function, and the role of ATP in U2 recruitment to splicing complexes.

\section{Is the ATP-independent prespliceosome-like complex an intermediate in prespliceosome formation?}

Our results demonstrate that CUS2 protein and the downstream region of U2 snRNA are regulators of prespliceosome assembly, blocking stable prespliceosome formation unless ATP is present (see Fig. 6). Importantly, they also suggest that there are two roles of ATP in prespliceosome assembly, one of which provides a regulatory signal (e.g., Fig. 1A) so that complex formation is inhibited in the absence of ATP, and the other which enhances the rate of prespliceosome assembly (e.g., Fig. $3 \mathrm{~B})$. Although it is generally held that U2 snRNP does not associate with pre-mRNA unless ATP is present, there are reported instances of prespliceosome-like complexes that form under some circumstances (Jamison and Garcia-Blanco 1992; Liao et al. 1992; Hong et al. 1997; Query et al. 1997). In contrast to our results (Fig. 2), there has been no demonstration that any of these complexes lead to functional spliceosomes. A model of the mammalian A complex (prespliceosome) called Amin has been described, whose formation is dependent on ATP if the pre-mRNA substrate extends upstream of the branchpoint, but is ATP-independent when the substrate contains only the branchpoint and polypyrimidine tract (Query et al. 1997). Together with our results, the loss of ATP dependence for Amin formation (Query et al. 1997) indicates a role for pre-mRNA sequences, possibly those that interact with SF3b subunits (Gozani et al. 1996) in enforcing ATP dependence of prespliceosome formation.

In addition to their ATP-independent formation, Amin complexes are dissociated by ATP, suggesting that the association of U2 snRNP with pre-mRNA is dynamically unstable (Query et al. 1997). A weak association of U2 snRNP components with mammalian commitment complexes (E complex; Michaud and Reed 1991) has also been reported in the absence of ATP (Hong et al. 1997). In a key experiment, Rosbash and colleagues attempted to detect an advantage in spliceosome assembly for U2 snRNPs allowed time to associate with commitment complex in the absence of ATP; such an advantage would be expected if a weak biochemical association were merely stabilized by ATP (Liao et al. 1992). Surprisingly, allowing time for association of commitment complexes with U2 snRNP in the absence of ATP provided no advantage, and a second pool of marked U2 snRNP added at the time of ATP was equally represented in the functional population of spliceosomes (Liao et al. 1992). Thus, no functional association between U2 snRNP and commitment complexes could be demonstrated in the absence of ATP. In contrast, we find that functional complexes can be stabilized in the absence of ATP in mutant extracts, such as those lacking CUS2 (Figs. 1-4), or with mutations that perturb U2 RNA structure (Fig. 5). Whereas loss of CUS2 can stabilize the functional ATP-independent complex (the prespliceo- 
some-like complex), addition of rCUS2 after the complex is formed cannot destabilize its formation (data not shown). Thus, CUS2 can inhibit the initial formation of the prespliceosome-like complex but cannot destabilize it once it is formed. These observations together with those of Liao et al. (1992), indicate that CUS2 and correct U2 RNA structure probably act to prevent the association of U2 snRNP with commitment complexes unless ATP is present, either by blocking binding or enhancing dissociation in the absence of ATP. In this view, the absence of CUS2, or the adoption of appropriate U2 structure traps the U2 snRNP in a competent state for binding, the net effect of which is to allow formation of prespliceosomes in the absence of ATP.

ATP-dependent control of splicing mediated by CUS2 is likely to be conserved. We and others have found putative CUS2 homologs in Schizosaccharomyces pombe (the essential gene UAP2; McKinney et al. 1997), Drosophila melanogastor (ORF LD29055), fish (tFZR1; Ito et al. 1998), and mammalian cells (Tat-SF1; Zhou and Sharp 1996; Yan et al. 1998). In addition, the step-loop IIa of U2 and its antagonistic downstream element are phylogentically conserved (Ares and Igel 1990; Zavanelli and Ares 1991; Zavanelli et al. 1994). How the function of Tat-SF1 in in vitro transcription (Zhou and Sharp 1996; Li and Green 1998) reflects its possible role in splicing is not yet clear, although immunoprecipitation experiments show that Tat-SF1 is associated with SF3a proteins in splicing extracts (Yan et al. 1998). It is possible, on the basis of our results, that depletion of TatSF1 will not block splicing, but may make prespliceosome formation ATP independent in mammalian extracts. Recent work on the minor spliceosomal components, U11 and U12 snRNP, has shown that they bind a U12dependent intron in the absence of ATP to form a spliceosomal complex formally equivalent to the prespliceosome of the major splicing pathway (Frilander and Steitz 1999|. To the extent that the major and minor spliceosomes share features such as the SF3b proteins (Will et al. 1999|, these findings also support a regulatory, rather than an obligate role for ATP in prespliceosome assembly. Because there are very few U12-dependent introns in the genome, the minor spliceosome may not need the stringent ATP-dependent regulation required to control the far more active major spliceosome.

\section{Materials and methods}

In vitro splicing and native gel analysis

Splicing extracts were isolated as described and derive from yeast strain RP01 (Yan et al. 1998) cotransformed with pRS314CUS2 (CUS2+) or pRS314 (CUS2 $\Delta$ ) and U2 genes on a LEU2 plasmid. A total of $10 \mu \mathrm{l}$ of splicing reactions containing $4 \mathrm{nM}$ of substrate (preactin, mutant, or wild-type pre-RP51A), and native gel analysis were as described (Zavanelli and Ares 1991), except that the acrylamide/bis-acrylamide ratio is 80:1.9. Note that prespliceosomes and spliceosomes do not resolve separately in this native gel system. Splice reactions were done at $25^{\circ} \mathrm{C}$. Plasmids for transcription of RP51A pre-mRNAs were from M. Rosbash (Howard Hughes Medical Institute, Brandeis
University, Boston, MA). ATP depletion was done by incubating splicing extracts and splicing buffer for 10 mins with $0.2 \mathrm{~mm}$ glucose before adding pre-mRNA (Liao et al. 1992). Reactions containing $2 \mathrm{mM}$ ATP or $2 \mathrm{mM}$ AMP-PCP were done by addition to ATP-depleted extracts.

\section{In vitro $U$ snRNA depletions}

U snRNA depletions were done by addition of one of U1, U2, or U6 snRNA-specific oligonucleotides at 125, 45, and $30 \mathrm{nM}$, respectively to splicing extracts containing splicing buffer, but prior to addition of $0.2 \mathrm{~mm}$ glucose. Incubation was $15 \mathrm{~min}$ at $25^{\circ} \mathrm{C}$. The control oligonucleotide (lanes M) is CUP1 (Howe and Ares 1997). Oligonucleotide sequences are U1, 5'-TCTTAAGGTAAGTAT-3'; U2, 5' -CAGATACTACACTTG-3' (McPheeters et al. 1989); U6, 5'-ATCTCTGTATTGTTTCAAATT-3' (Fabrizio et al. 1989).

\section{rCUS2/rY48D add-backs}

Plasmids and purification of rCUS2 and rY48D are described in Yan et al. (1998). Recombinant proteins or protein dilution buffer were added to splicing mixes containing splice extract, buffer, and $0.2 \mathrm{~mm}$ glucose and incubated for $10 \mathrm{~min}$ at $25^{\circ} \mathrm{C}$, prior to addition of pre-mRNA substrate.

\section{The chase experiment}

The ATP-independent prespliceosomes were chased to spliceosomes as follows: Extracts were ATP depleted and split into two treatments (1 and 2; see Fig. 2A). Treatment 1 had 45 nм U2 oligonucleotide, treatment 2 had $\mathrm{H}_{2} \mathrm{O}$. Both treatments were incubated at $25^{\circ} \mathrm{C}$ for $15 \mathrm{~min}$, then $40 \mathrm{~nm}$ of preactin substrate was added and both were incubated for a further $15 \mathrm{~min}$ at $25^{\circ} \mathrm{C}$. Treatment 2 then had $45 \mathrm{~nm} \mathrm{U} 2$ oligonucleotide, treatment 1 had $\mathrm{H}_{2} \mathrm{O}$, and each was incubated at $25^{\circ} \mathrm{C} 15 \mathrm{~min}$. Treatments 1 and 2 were then split, and 2 mM ATP was added to one tube from treatment 1 and one tube from treatment 2. Treatments were incubated for a final $15 \mathrm{~min}$ at $25^{\circ} \mathrm{C}$ and splice products or native gel analysis analyzed as described (Zavanelli and Ares 1991).

\section{prp5- $1 \times$ CUS $2 \Delta$ and prp5-3 $\times$ CUS $2 \Delta$ crosses}

SRY5-1b or SRY5-3b (Ruby et al. 1993) and HI227CUS2A (Yan et al. 1998) were crossed and sporulated by standard techniques (Guthrie and Fink 1991) except that the prp5-3 × CUS28 diploid was transformed with pRS316CUS2+ prior to sporulation. The strain prp5-1 $\times$ CUS2 $\Delta$ is named RP516-2. RP516-2 was transformed with pRS316 or pRS316CUS2+ and selected on -URAHIS to make isogenic CUS2+ and CUS2 $\Delta$ strains. Splicing extracts and native gel analysis of spliceosome assembly was as described above with the following exception. Restrictive $\left(37^{\circ} \mathrm{C}\right)$ and permissive $\left(25^{\circ} \mathrm{C}\right)$ temperature incubations of each extract was done for $10 \mathrm{~min}$ prior to the addition of pre-mRNA and ATP or $\mathrm{H}_{2} \mathrm{O}$. ATP depletion was also done during this preincubation.

\section{prp5-1 rescue by CUS2 suppressor proteins}

SRY5-1b was transformed with pRS316 or this plasmid carrying CUS2+, CUS2-Y48D, or one of the CUS2 suppressors, CUS2-9 or CUS2-25, and selected on -URA. Individual colonies were restreaked on -URA and incubated at $25^{\circ} \mathrm{C}$ and $36^{\circ} \mathrm{C}$ for 4 days. 


\section{Acknowledgments}

We thank Roland Nagel and Marc Spingola for advice and comments on the manuscript, Haller Igel for technical assistance, Michael Rosbash for providing pre-RP51A plasmids, and Stephanie Ruby for temperature-sensitive PRP5 strains. R.P. was supported by an American Cancer Society Posdoctoral Fellowship. This work was also supported by grant GM47408 from the National Institutes of Health to M.A.

The publication costs of this article were defrayed in part by payment of page charges. This article must therefore be hereby marked "advertisement" in accordance with 18 USC section 1734 solely to indicate this fact.

\section{References}

Ares, M., Jr. and A.H. Igel. 1990. Lethal and temperature sensitive mutations and their suppressors identify an essential structural element in U2 small nuclear RNA. Genes \& Dev. 4: 2132-2145.

Ares, M., Jr. and B. Weiser. 1995. Rearrangement of snRNA structure during assembly and function of the spliceosome. Prog. Nucleic Acid Res. 50: 131-159.

Behrens, S.E., F. Galsson, P. Legrain, and R. Luhrmann. 1993. Evidence that the $60-\mathrm{kDa}$ protein of $17 \mathrm{~S}$ U2 small nuclear ribonucleoprotein is immunologically and functionally related to the yeast PRP9 splicing factor and is required for the efficient formation of prespliceosomes. Proc. Natl. Acad. Sci. 90: 8229-8233.

Birney, E., S. Kumar, and A.R. Krainer. 1993. Analysis of the RNA-recognition motif and RS and RGG domains: Conservation in metazoan pre-mRNA splicing factors. Nucleic Acids Res. 21: 5803-5816.

Brosi, R., K. Groning, S.E. Behrens, R. Luhrmann, and A. Kramer. 1993. Interaction of mammalian splicing factor SF3a with U2 snRNP and relation of its $60-\mathrm{kD}$ subunit to yeast PRP9. Science 262: 102-105.

Caspary, F., A. Shevchenko, M. Wilm, and B. Seraphin. 1999. Partial purification of the yeast U2 snRNP reveals a novel yeast pre-mRNA splicing factor required for pre-spliceosome assembly. EMBO J.18: 3463-3474.

Dalbadie-McFarland, G. and J. Abelson. 1990. PRP5: A helicaselike protein required for mRNA splicing in yeast. Proc. Natl. Acad. Sci. 87: 4236-4240.

Fabrizio, P., D.S. McPheeters, and J. Abelson. 1989. In vitro assembly of yeast U6 snRNP: A functional assay. Genes \& Dev. 12B: 2137-2150.

Fleckner, J., M. Zhang, J. Valcarcel, and M.R. Green. 1997. U2AF65 recruits a novel human DEAD box protein required for the U2 snRNP-branchpoint interaction. Genes \& Dev. 11: $1864-1872$.

Frilander, M.J. and J.A. Steitz. 1999. Initial recognition of U12dependent introns requires both U11/5' splice-site and U12/ branchpoint interactions. Genes \& Dev. 13: 851-863.

Gozani, O., R. Feld, and R. Reed. 1996. Evidence that sequenceindependent binding of highly conserved U2 snRNP proteins upstream of the branch site is required for assembly of spliceosomal complex A. Genes \& Dev. 10: 233-243.

Guthrie, C. and G. Fink. 1991. Guide to yeast genetics and molecular biology. Academic Press, San Diego, CA.

Hong, W., M. Bennett, Y. Xiao, R. Feld Kramer, C. Wang, and R. Reed. 1997. Association of U2 snRNP with the spliceosomal complex E. Nucleic Acids Res. 25: 354-361.

Howe, K.J. and M. Ares, Jr. 1997. Intron self-complementarity enforces exon inclusion in a yeast pre-mRNA. Proc. Natl. Acad. Sci. 94: 12467-12472.
Igel, H., S. Wells, R. Perriman, and M. Ares, Jr. 1998. Conservation of structure and subunit interactions in yeast homologues of splicing factor $3 \mathrm{~b}$ (SF3b) subunits. RNA 4: 1-10.

Ito, M., A. Masuda, K. Yumoto, A. Otomo, Y. Takahashi, N. Takamatsu, H. Kanda, S. Yamashita, and T. Shiba. 1998. cDNA cloning of a new member of the FTZ-F1 subfamily from a rainbow trout. Biochim. Biophys. Acta 1395: 271274.

Jamison, S.F. and M.A. Garcia-Blanco. 1992. An ATP-independent U2 small nuclear ribonucleoprotein particle/precursor mRNA complex requires both splice sites and the polypyrimidine tract. Proc. Natl. Acad. Sci. 89: 5482-5486.

Kenan, D.J., C.C. Query, and P.A. Sharp. 1991. RNA recognition: Towards identifying determinants of specificity. Trends Biochem. Sci. 16: 214-220.

Kramer, A. 1996. The structure and function of proteins involved in mammalian pre-mRNA splicing. Annu. Rev. Biochem. 65: 367-409.

Kramer, A., P. Gruter, K. Groning, and B. Kastner. 1999. Combined biochemical and electron microscopic analyses reveal the architecture of the mammalian U2 snRNP. J. Cell Biol. 145: $1355-1368$.

Legrain, P., B. Seraphin, and M. Rosbash. 1988. Early commitment of yeast pre-mRNA to the spliceosome pathway. Mol. Cell. Biol. 8: 3755-3760.

Li, X.Y. and M.R. Green. 1998. The HIV-1 Tat cellular coactivator Tat-SF1 is a general transcription elongation factor. Genes \& Dev. 12: 2992-2996.

Liao, X.C., H.V. Colot, Y. Wang, and M. Rosbash. 1992. Requirements for U2 snRNP addition to yeast pre-mRNA. Nucleic Acids Res. 20: 4237-4245.

McKinney, R., K. Wentz-Hunter, H. Schmidt, and J. Potashkin. 1997. Molecular characterization of a novel fission yeast gene spUAP2 that interacts with the splicing factor spU2AF59. Curr. Genet. 32: 323-330.

McPheeters, D.S., P. Fabrizio, and J. Abelson. 1989. In vitro reconstitution of functional yeast U2 snRNPs. Genes \& Dev. 12B: 2124-2136.

Michaud, S. and R. Reed. 1991. An ATP-independent complex commits pre-mRNA to the mammalian spliceosome assembly pathway. Genes \& Dev. 12B: 2534-2546.

Moore, M.J., C.C. Query, and P.A. Sharp. 1993. Splicing of precursors to mRNA in the spliceosome. In The RNA world (ed. R.F. Gesteland and J.F. Atkins), pp. 303-357. Cold Spring Harbor Laboratory Press, Cold Spring Harbor, NY.

Nagai, K., C. Oubridge, N. Ito, J. Avis, and P. Evans. 1995. The RNP domain: A sequence-specific RNA-binding domain involved in processing and transport of RNA. Trends Biochem. Sci. 20: 235-240.

O'Day, C.L., G. Dalbadie-McFarland, and J. Abelson. 1996. The Saccharomyces cerevisiae Prp5 protein has RNA-dependent ATPase activity with specificity for U2 small nuclear RNA. J. Biol. Chem. 271: 33261-33267.

Pauling, M.H., D.S. McPheeters, and M. Ares, Jr. 2000. Functional Cus1p is found with Hsh155p in a multiprotein splicing factor associated with U2 snRNA. Mol. Cell. Biol. (in press).

Query, C.C., P.S. McCaw, and P.A. Sharp. 1997. A minimal spliceosomal complex A recognizes the branch site and polypyrimidine tract. Mol. Cell. Biol. 17: 2944-2953.

Ruby, S.W. 1997. Dynamics of the U1 small nuclear ribonucleoprotein during yeast spliceosome assembly. J. Biol. Chem. 272: $17333-17341$.

Ruby, S.W. and J. Abelson. 1988. An early hierarchic role of U1 small nuclear ribonucleoprotein in spliceosome assembly. Science 242: 1028-1035. 
Ruby, S.W., T.H. Chang, and J. Abelson. 1993. Four yeast spliceosomal proteins (PRP5, PRP9, PRP11, and PRP21) interact to promote U2 snRNP binding to pre-mRNA. Genes \& Dev. 7: 1909-1925.

Schmidt-Zachmann, M.S., S. Knecht, and A. Kramer. 1998. Molecular characterization of a novel, widespread nuclear protein that colocalizes with spliceosome components. Mol. Biol. Cell 9: 143-160.

Schwer, B. and C.H. Gross. 1998. Prp22, a DExH-box RNA helicase, plays two distinct roles in yeast pre-mRNA splicing. EMBO J.17: 2086-2094.

Seraphin, B. and M. Rosbash. 1989. Identification of functional U1 snRNA-pre-mRNA complexes committed to spliceosome assembly and splicing. Cell 59: 349-358.

- 1991. The yeast branchpoint sequence is not required for the formation of a stable U1 snRNA-pre-mRNA complex and is recognized in the absence of U2 snRNA. EMBO J.10: 1209-1216.

Staley, J.P. and C. Guthrie. 1998. Mechanical devices of the spliceosome: Motors, clocks, springs, and things. Cell 92: 315-326.

Wang, C., K. Chua, W. Seghezzi, E. Lees, O. Gozani, and R. Reed. 1998. Phosphorylation of spliceosomal protein SAP 155 coupled with splicing catalysis. Genes \& Dev. 12: 1409_ 1414.

Wells, S.E. and M. Ares, Jr. 1994. Interactions between highly conserved U2 small nuclear RNA structures and Prp5p, Prp9p, Prp11p, and Prp21p proteins are required to ensure integrity of the U2 small nuclear ribonucleoprotein in Saccharomyces cerevisiae. Mol. Cell. Biol. 14: 6337-6349.

Wells, S.E., M. Neville, M. Haynes, J. Wang, H. Igel, and M. Ares, Jr. 1996. CUS1, a suppressor of cold-sensitive U2 snRNA mutations is a novel yeast splicing factor homologous to human SAP145. Genes \& Dev. 10: 220-232.

Wiest, D.K., C.L. O'Day, and J. Abelson. 1996. In vitro studies of the Prp9.Prp11.Prp21 complex indicate a pathway for U2 small nuclear ribonucleoprotein activation. J. Biol. Chem. 271: 33268-33276.

Will, C.L., C. Schneider, R. Reed, and R. Luhrmann. 1999. Identification of both shared and distinct proteins in the major and minor spliceosomes. Science 284: 2003-2005.

Wilson, K.S. and H.F. Noller. 1998. Molecular movement inside the translational engine. Cell 92: 337-349.

Yan, D., R. Perriman, H. Igel, K.J. Howe, M. Neville, and M. Ares, Jr. 1998. CUS2, a yeast homolog of human Tat-SF1 rescues function of misfolded U2 through an unusual RNA recognition motif. Mol. Cell. Biol. 18: 5000-5009.

Zavanelli, M.I. and M. Ares, Jr. 1991. Efficient association of U2 snRNPs with pre-mRNA requires an essential U2 RNA structural element. Genes \& Dev. 5: 2521-2533.

Zavanelli, M.I., J.S. Britton, A.H. Igel, and M. Ares, Jr. 1994. Mutations in an essential U2 small nuclear RNA structure cause cold-sensitive U2 small nuclear ribonucleoprotein function by favoring competing alternative U2 RNA structures. Mol. Cell. Biol. 14: 1689-1697.

Zhou, Q. and P.A. Sharp. 1996. Tat-SF1: Cofactor for stimulation of transcriptional elongation by HIV-Tat. Science 274: 605-610. 


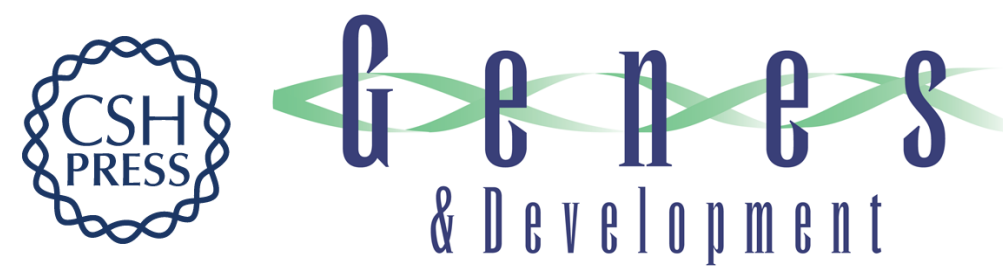

\section{ATP can be dispensable for prespliceosome formation in yeast}

Rhonda Perriman and Manuel Ares, Jr.

Genes Dev. 2000, 14:

Access the most recent version at doi:10.1101/gad.14.1.97

References This article cites 46 articles, 29 of which can be accessed free at: http://genesdev.cshlp.org/content/14/1/97.full.html\#ref-list-1

License

Email Alerting Receive free email alerts when new articles cite this article - sign up in the box at the top Service right corner of the article or click here.

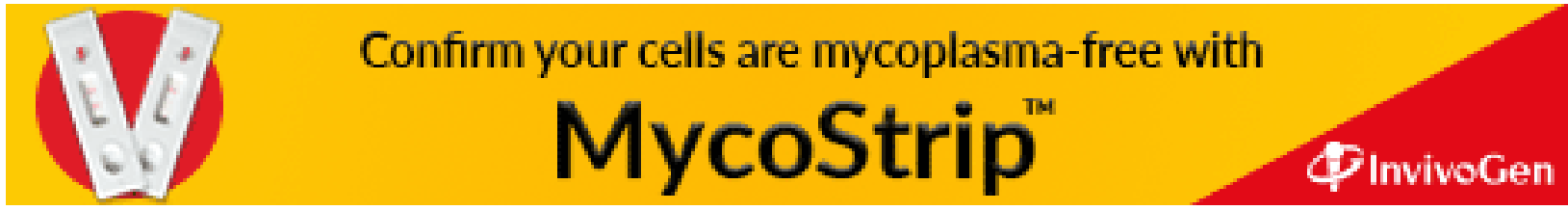

